Open Access

\title{
Erratum to: Customer service quality and benchmarking in public transport contracts
}

David A. Hensher

Correspondence: David.Hensher@ sydney.edu.au

Institute of Transport and Logistics Studies (ITLS), The University of Sydney Business School, The

University of Sydney, Sydney 2006 NSW, Australia
The original version of this article [1] unfortunately contained a mistake. The citation of the article was incorrect in the PDF version of this article. The correct citation number is 4 . The citation has now been corrected in the original article.

Published online: 12 August 2015

\section{Reference}

1. Hensher DA (2015) Customer service quality and benchmarking in public transport contracts. Int J Qual Innov $1(1): 4$ (c) 2015 Hensher. Open Access This article is distributed under the terms of the Creative Commons Attribution 4.0 International License (http://creativecommons.org/licenses/by/4.0/), which permits unrestricted use, distribution, and reproduction in any medium, provided you give appropriate credit to the original author(s) and the source, provide a link to the Creative Commons license, and indicate if changes were made. 